\title{
Effects of moguisteine, a peripheral nonnarcotic antitussive agent, on airway inflammation in guinea-pigs in vivo
}

\author{
L. Gallico, N. Oggioni, C. Dalla Rosa, R. Ceserani, S. Tognella
}

\begin{abstract}
Effects of moguisteine, a peripheral nonnarcotic antitussive agent, on airway inflammation in guinea-pigs in vivo. L. Gallico, N. Oggioni, C. Dalla Rosa, R. Ceserani, S. Tognella. CERS Journals Ltd 1996.

ABSTRACT: Cough is a common symptom of respiratory diseases associated with irritation or inflammation of the airways, and symptomatic antitussive drugs are frequently prescribed to control an abnormal cough reflex. Our aim was to evaluate the effects of moguisteine, a novel, peripheral, nonnarcotic antitussive agent, on airway inflammation induced in guinea-pigs with a variety of stimuli.

These stimuli included exposure to tobacco smoke for $10 \mathrm{~min}$, to elicit airway hyperreactivity, eosinophil recruitment in bronchoalveolar lavage (BAL), airway epithelial damage and plasma exudation; graded platelet-activating factor (PAF) infusion (600 $\mathrm{ng}^{\cdot \mathrm{kg}^{-1}}$ over one $\left.\mathrm{h}\right)$, to induce airway hyperreactivity; $2 \%$ ovalbumin (OA) aerosol challenge in 1\% OA-sensitized animals, to induce late-phase (17 and $72 \mathrm{~h}$ ) airway leucocyte accumulation. We also assessed the activity of moguisteine on plasma leakage induced by capsaicin, on bronchoconstriction induced by acetylcholine (ACh), histamine (H) and PAF, and on leukotriene mediated allergic bronchospasm in OA-sensitized guinea-pig.

Moguisteine (p.o. and i.m.) and dexamethasone (p.o. and i.m.) dose-dependently reduced tobacco smoke-induced bronchial hyperreactivity. Moguisteine and dexamethasone abolished eosinophil recruitment in BAL, prevented the sloughing of the epithelium and significantly reduced airway microvascular leakage. Both agents were also highly effective in reducing bronchial hyperreactivity elicited by PAF infusion. In addition, moguisteine was active in inhibiting airway neutrophil and eosinophil accumulation in BAL observed 17 and $72 \mathrm{~h}$ after $\mathrm{OA}$ challenge in sensitized guinea-pigs. In contrast to dexamethasone, moguisteine did not prevent capsaicin-induced plasma leakage. It was also ineffective against bronchoconstriction as induced by $\mathrm{ACh}, \mathrm{H}$, and PAF and failed to inhibit leukotriene-dependent bronchospasm.

Our data suggest that moguisteine represents an antitussive compound endowed with interesting airway anti-inflammatory properties in guinea-pigs in vivo. Its mechanism of action remains to be elucidated.
\end{abstract}

Eur Respir J., 1996, 9, 478-485.
Boehringer Mannheim Italia, Research Center, Monza, Italy.

Correspondence: L. Gallico

Boehringer Mannheim Italia

Research Center

Viale della Libertà

$\mathrm{Km} 0.750$

I-20052 Monza

Italy

Keywords: Airway microvascular leakage bronchial hyperreactivity experimental airway inflammation leukocyte infiltration moguisteine

Received: January 231995 Accepted after revision October 251995
A variety of factors are responsible for cough: exposure to irritant gases and fumes, tobacco smoke, viral respiratory infection, chronic bronchitis, asthma and postnasal drip syndrome [1]. All these conditions appear to be associated with a common basic feature, i.e. irritation and/or inflammation of the airways, which can increase the responsiveness of laryngeal and tracheobronchial rapidly adapting irritant receptors, which evoke cough $[2,3]$.

It is widely-accepted that the rational direction for cough therapy should be toward the diagnosis and the treatment of the underlying disease [1], although symptomatic antitussive drugs, such as codeine or dextromethorphan, are frequently prescribed to control an abnormal cough reflex. Thus, used in combination with drugs that are specific to the causal disease, an antitussive drug endowed with airway anti-inflammatory properties could represent an innovative tool for cough therapy.

Moguisteine, ethyl (R,S)-2-(2-methoxyphenoxy) methyl$\beta$-oxo-3-(1,3-thiazolidine) propanoate, is a novel peripheral nonnarcotic antitussive agent that has proved to be as active as codeine in several experimental models of induced cough in guinea-pigs and $\operatorname{dogs}[4,5]$. It acts neither through the opiate receptors nor on the cough centre, and its action is possibly mediated by the interaction with rapidly adapting irritant receptors along the tracheobronchial tree [4]. In controlled clinical trials, moguisteine has been shown to be safe and to effectively reduce cough associated with such respiratory disorders as acute upper respiratory tract infection, chronic bronchitis, pulmonary fibrosis and malignancies [69]. 
This paper describes the anti-inflammatory activity of moguisteine in comparison with dexamethasone in a model of guinea-pig airway inflammation induced by a variety of stimuli, such as cigarette smoke exposure, platelet-activating factor (PAF) infusion and allergen inhalation. All of the chosen stimuli have been described as producing inflammatory reactions that are characterized by bronchial hyperreactivity, airway leucocyte recruitment and airway microvascular leakage [10-12].

\section{Materials and methods}

\section{Animals}

Male Dunkin Hartley barrier-bred guinea-pigs (Charles River, Italy), weighing 350-400 g were maintained in conditioned quarters (temperature $21 \pm 2^{\circ} \mathrm{C}$, relative humidity $55 \pm 10 \%, 12 \mathrm{~h}$ on/12 h off light cycle) with standard diet and water ad libitum for at least 1 week before use.

\section{Airway inflammation induced by cigarette smoke inhala-} tion

Bronchial hyperreactivity to acetylcholine. The guineapigs were anaesthetized with urethane $\left(1.25 \mathrm{~g} \cdot \mathrm{kg}^{-1} i . p.\right)$, tracheotomized and ventilated via a tracheal cannula connected to a ventilatory pump (Rodent ventilator, mod. 7025, Basile, Italy) at 55 strokes $\cdot \mathrm{min}^{-1}$ with $1 \mathrm{~mL}$ of air per $100 \mathrm{~g}$ body weight (BW). A jugular vein was also cannulated for drug injection. In order to suppress spontaneous breathing, pancuronium bromide $\left(2 \mathrm{mg} \cdot \mathrm{kg}^{-1} i . v\right.$. $)$ was injected. Bronchoconstriction, expressed as increase in pulmonary inflation pressure (PIP; $\mathrm{mmHg}$ ), was measured with a pressure transducer (Bell and Howell, model 4-3271) connected to the inspiration line of the ventilatory circuit. The signals were recorded on a polygraph (Beckman type R611).

A slight bronchoconstriction (PIP 3-5 mmHg) was induced with acetylcholine (ACh) $2.5-5 \mu \mathrm{g} \cdot \mathrm{kg}^{-1} i . v$.; after at least two reproducible responses with a fixed dose of $\mathrm{ACh}$, the animals inhaled tobacco smoke produced by high-tar, commercially available cigarettes (Stop, Monopoli di Stato, Italy); inhalation was through the ventilatory circuit for $15 \mathrm{~s} \cdot \mathrm{min}^{-1}$ for ten min [10]. After $5 \mathrm{~min}$, all guinea-pigs were challenged with the same dose of ACh, and hyperresponsiveness was measured as the increase in bronchoconstriction in comparison with the basal value.

Airway leucocyte recruitment. Cytological studies were undertaken in separate experiments on bronchoalveolar lavage (BAL). These experiments were carried out in the guinea-pigs 5 min after smoke exposure, as described above. BAL was performed by gentle washing of the lungs with $3 \times 10 \mathrm{~mL}$ aliquots of sterile saline at $37^{\circ} \mathrm{C}$, administered with a syringe via the tracheal cannula. The total cell number present in the recovered fluid (about $28 \mathrm{~mL}$ ) was counted with a Coulter counter (ZM-Coulter Scientific), and the differential cell count was undertaken on cytocentrifuged $(1,200 \mathrm{rpm})$ preparations (Cytospin II Shandon) stained with Diff-Quik ${ }^{\circledR}$. Standard morphological criteria were used to classify cells into lymphocytes, neutrophils, eosinophils, macrophages and epithelial cells. At least 300 cells were counted for each sample by an investigator who was unaware of the treatment group assignments.

Airway microvascular leakage. To assess the effect of cigarette smoke on airway plasma exudation, Evans blue dye was injected i.v. $\left(25 \mathrm{mg} \cdot \mathrm{kg}^{-1}\right) 15 \mathrm{~min}$ prior to exposure to cigarette smoke, as described above. Thirty minutes after dye administration (i.e. 5 min after cigarette smoke inhalation), the intravascular dye was removed by perfusion through the aorta with $100 \mathrm{~mL}$ of saline at $37^{\circ} \mathrm{C}$; a small incision was made in the right atrium to allow the outflow of the blood and of the perfusate. For the extraction of the dye, the trachea (about $1 \mathrm{~cm}$ above the bifurcation) and the main bronchi were then removed, weighed and incubated in formamide for $24 \mathrm{~h}$ at $50^{\circ} \mathrm{C}$. The concentration of Evans blue was quantified as light absorbance at $620 \mathrm{~nm}$ (spectrophotometer Uvikon 930, Kontron Instrument) by interpolation on a standard curve $\left(0.4-8 \mu \mathrm{g} \cdot \mathrm{mL}^{-1}\right.$ in formamide). The dye content was expressed as $\mathrm{ng} \cdot \mathrm{mg}^{-1}$ of tissue. The percentage inhibition of Evans blue dye extravasation produced by the compounds was determined as follows:

$$
\% \text { Inhibition }=100-\frac{\text { treated }- \text { unexposed }}{\text { vehicle }- \text { unexposed }} \times 100
$$

where "treated" corresponds to tissue Evans blue dye content in tobacco smoke-exposed and compound-treated guinea-pigs, "unexposed" corresponds to tissue Evans blue dye content in non-tobacco smoke-exposed guineapigs, and "vehicle" corresponds to tissue Evans blue dye content in tobacco smoke-exposed and vehicle-treated guinea-pigs.

Moguisteine was given, respectively, at 7.5, 15 and 30 $\mathrm{mg} \cdot \mathrm{kg}^{-1}$ p.o. and at $0.3,0.6,1.25$ and $2.5 \mathrm{mg} \cdot \mathrm{kg}^{-1}$ i.m., 90 and 120 min before cigarette smoke exposure (bronchial hyperreactivity to acetylcholine) and at $30 \mathrm{mg} \cdot \mathrm{kg}^{-1}$ p.o. (airway leucocyte recruitment, and airway microvascular leakage). Dexamethasone was injected i.m. at 0.3 , $0.6,1.25$ and $2.5 \mathrm{mg} \cdot \mathrm{kg}^{-1} 7 \mathrm{~h}$ before cigarette smoke exposure (bronchial hyperreactivity to acetylcholine) and at $2.5 \mathrm{mg} \cdot \mathrm{kg}^{-1}$ i.m. (airway leucocyte recruitment, and airway microvascular leakage). Six animals were used per dose level.

\section{Airway microvascular leakage induced by capsaicin}

Guinea-pigs were anaesthetized with urethane (1.25 $\mathrm{g} \cdot \mathrm{kg}^{-1}$ i.p.) and a small plastic catheter (PE 10) was inserted into the trachea through a slight incision immediately under the larynx. The tip of the tube was fixed at $1 \mathrm{~cm}$ under the larynx. The animals were then kept in the supine position on a table inclined to $40^{\circ}$. Capsaicin was intratracheally infused at a constant infusion rate 
(0.2 nM; $\left.0.02 \mathrm{~mL} \cdot \mathrm{min}^{-1}\right)$ for $2 \mathrm{~min}$ with an infusion pump (Vial Medical SE 2000, Omeda, Italy), which was connected to the catheter [13]. Evans blue dye (25 $\mathrm{mg} \cdot \mathrm{mL}^{-1} \cdot \mathrm{kg}^{-1}$ in saline $1 \mathrm{~min}$ before capsaicin infusion) was injected into the jugular vein for plasma leakage evaluation. The intravascular dye was removed, $10 \mathrm{~min}$ after capsaicin infusion, as above. A $1 \mathrm{~cm}$ piece of trachea, just before bifurcation, and the left and right main bronchi, were excised and weighed. Evans blue extraction and determination were performed as above.

Moguisteine $\left(60 \mathrm{mg} \cdot \mathrm{kg}^{-1}\right.$ p.o.) was given 30,60 or 90 min before capsaicin, and dexamethasone $\left(7.5 \mathrm{mg} \cdot \mathrm{kg}^{-1}\right.$ p.o.) $7 \mathrm{~h}$ before.

\section{Bronchial hyperreactivity to histamine induced by PAF}

Guinea-pigs were prepared for the recording of PIP as described above. Bronchoconstriction (PIP 2-6 $\mathrm{mmHg}$ ) was induced by the injection of $1-5 \mu \mathrm{g} \cdot \mathrm{kg}^{-1}$ histamine $(\mathrm{H})$ into the jugular vein. When at least two reproducible responses had been obtained, a graded i.v. infusion of PAF was started $\left(3 \mathrm{ng} \cdot \mathrm{min}^{-1}\right.$ for $10 \mathrm{~min}, 6 \mathrm{ng} \cdot \mathrm{min}^{-1}$ for $20 \mathrm{~min}, 15 \mathrm{ng} \cdot \mathrm{min}^{-1}$ for $30 \mathrm{~min}$ of the total dose received, i.e. $600 \mathrm{ng} \cdot \mathrm{kg}^{-1} \cdot \mathrm{h}$ ) [11]. Ten minutes after the end of infusion, the animals were injected with histamine and hyperreactivity to histamine was measured as the increase in bronchoconstriction in comparison with the basal value.

Moguisteine was given at 7.5, 15 and $30 \mathrm{mg} \cdot \mathrm{kg}^{-1}$ intraduodenal (i.d.) 7 min before PAF infusion; this timing was selected on the basis of preliminary time-course studies. Dexamethasone was administered at 1.7, 3.5 and $7.5 \mathrm{mg} \cdot \mathrm{kg}^{-1}$ p.o. $7 \mathrm{~h}$ before PAF. Seven to eight animals were used per dose level.

\section{Bronchoconstriction induced by acetylcholine, histamine and $P A F$}

Guinea-pigs were prepared for the recording of PIP as described above. Bronchoconstriction (PIP 12-25 mmHg) was induced by i.v. injection of ACh (10-20 $\left.\mu \mathrm{g} \cdot \mathrm{kg}^{-1}\right)$, of histamine $\left(5-10 \mu \mathrm{g} \cdot \mathrm{kg}^{-1}\right)$ and of PAF $\left(50 \mathrm{ng} \cdot \mathrm{kg}^{-1}\right)$. After at least two constant bronchoconstricting responses (basal values) to ACh or histamine, moguisteine was given; and, thereafter, the agonists were reinjected. In PAF experiments, since this agonist does not give reproducible bronchoconstricting responses in a single given animal, the activity was assessed against a control group.

Moguisteine, $5 \mathrm{mg} \cdot \mathrm{kg}^{-1}$ i.v., was given $1 \mathrm{~min}$ before the agonist challenge. Six animals were used per group.

\section{Late-phase airway leucocyte accumulation in sensitized guinea-pigs}

Guinea-pigs were sensitized by exposure for $3 \mathrm{~min}$ to aerosolized $1 \%$ ovalbumin (OA) solution in saline on Days 0 and 7. The aerosol was generated by an ultrasonic nebulizer (GB-Elbisonic, Italy) with an output of
$0.5 \mathrm{~mL} \cdot \mathrm{min}^{-1}$ and a particle size of $0.5-6 \mu \mathrm{m}$. Seven days later, the animals were pretreated with mepyramine maleate $\left(10 \mathrm{mg} \cdot \mathrm{kg}^{-1}\right.$ i.p. $) 30 \mathrm{~min}$ prior to challenge with an aerosol of $2 \% \mathrm{OA}$ in saline for $3 \mathrm{~min}$. BAL, performed as described above, was undertaken 17 and $72 \mathrm{~h}$ later [12], and its cytological analysis by cytocentrifuged preparation (see above) allowed evaluation of the airway leucocyte accumulation that characterizes late airway reaction. The differential cell counts were performed blind.

Moguisteine was tested at 75 and $150 \mathrm{mg} \cdot \mathrm{kg}^{-1}$ p.o. 90 min before OA challenge, and dexamethasone at 4, 7.5 and $15 \mathrm{mg} \cdot \mathrm{kg}^{-1}$ p.o. $7 \mathrm{~h}$ before OA challenge. Six animals were used per dose level. The percentage inhibition of leucocyte recruitment produced by the compounds was determined as follows:

$$
\% \text { Inhibition }=100-\frac{\text { treated }- \text { baseline }}{\text { vehicle }- \text { baseline }} \times 100
$$

where "treated" corresponds to cell number of OAchallenged and compound-treated guinea-pigs, "baseline" corresponds to cell number of saline-challenged guineapigs, and "vehicle" corresponds to cell number of OAchallenged and vehicle-treated guinea-pigs.

\section{Leukotriene-mediated allergic bronchospasm in sensi- tized guinea-pigs}

Guinea-pigs were sensitized as described previously, and 7 days after the second OA exposure they were prepared for PIP recording (see above). The animals were pretreated as follows: 15 min before OA challenge, with propranolol (1 $\mathrm{mg} \cdot \mathrm{kg}^{-1}$ i.v.), to prevent a homeostatic sympathomimetic bronchodilator mechanism, and indomethacin $\left(5 \mathrm{mg} \cdot \mathrm{kg}^{-1} i . v\right.$.), to highlight the lipoxygenase pathway; and 10 min before OA challenge, with mepyramine maleate $\left(0.5 \mathrm{mg} \cdot \mathrm{kg}^{-1}\right.$ i.v. $)$, to block $\mathrm{H}_{1}$ receptors [14]. The guinea-pigs were then challenged with an aerosol of $1 \% \mathrm{OA}$ in saline for $5 \mathrm{~s}$, delivered by the nebulizer (Devilbiss Pulmosonic), with an output of $1 \mathrm{~mL} \cdot \mathrm{min}^{-1}$ and a particle size of 0.6-15 $\mu \mathrm{m}$; the nebulizer was connected in series with the ventilatory pump. This challenge provoked a leukotriene-dependent bronchoconstriction, which was measured as an increase in PIP [14].

Moguisteine was tested at $150 \mathrm{mg} \cdot \mathrm{kg}^{-1}$ p.o. $90 \mathrm{~min}$ before OA challenge, dexamethasone at $7.5,15$ and 30 $\mathrm{mg} \cdot \mathrm{kg}^{-1}$ p.o. $7 \mathrm{~h}$ before, the leukotriene antagonist FPL 55712 at $2.5,5$ and $10 \mathrm{mg} \cdot \mathrm{kg}^{-1}$ i.v. $30 \mathrm{~s}$ before OA challenge. The leukotriene biosynthesis inhibitors BW 755C and phenidone were tested, respectively, at 10, 20 and $30 \mathrm{mg} \cdot \mathrm{kg}^{-1}$ i.v. $5 \mathrm{~min}$ before, and 5, 10 and $20 \mathrm{mg} \cdot \mathrm{kg}^{-1}$ i.v. $1 \mathrm{~min}$ before $\mathrm{OA}$ challenge. The treatment times for FPL 55712, for BW 755C and for phenidone were selected on the basis of preliminary time-course studies. Six to 10 animals were used per dose level.

\section{Drugs and chemicals}

Urethane, histamine dihydrochloride, acetylcholine chloride, Evans blue dye, mepyramine maleate, propranolol, 
phenidone and ovalbumin grade III (Sigma Chemicals, USA) were dissolved in saline; pancuronium bromide (Pavulon, Organon Teknica); indomethacin (Sigma Chemicals, USA) was dissolved in $5 \% \mathrm{NaHCO}_{3}$ and diluted with saline; PAF, 1-O-hexadecyl-2-O-acetyl-sn-glycero3-phosphorylcholine, (Novobiochem, Switzerland) was dissolved in ethanol $\left(1 \mathrm{mg} \cdot \mathrm{mL}^{-1}\right)$, stored at $-18^{\circ} \mathrm{C}$ as stock solution, and dilutions of PAF in saline containing $0.25 \%$ bovine serum albumin (Sigma Chemicals, USA) were prepared immediately prior to use; capsaicin (Fluka Chemie, Buchs, Switzerland) was dissolved in saline containing $0.5 \%$ ethanol; FPL 55712 and BW 755C (synthesized in Boehringer Mannheim Italia Chemical Department) were dissolved in saline; dexamethasone (Sicor, Italy) and moguisteine (Boehringer Mannheim Italia) were dissolved in dimethylsulphoxide (Sigma Chemicals, USA) and diluted to the required concentrations with saline (for parenteral administration), or were suspended in $0.5 \%$ methylcellulose (Formenti, Italy) (for oral administration).

\section{Statistical analysis}

Results are expressed as mean \pm SEM. The significance of difference between treatment groups was assessed with the Dunn test [15]. The dose-effect relationship was evaluated with regression analysis, and median effective (ED50) values were determined with $95 \%$ confidence limits $(95 \% \mathrm{CL})$.

\section{Results}

\section{Airway inflammation induced by cigarette smoke inhala-} tion

Bronchial hyperreactivity to acetylcholine. ACh 2.5-5 $\mu \mathrm{g} \cdot \mathrm{kg}^{-1} i . v$. produced a slight increase in PIP (range 3-5 $\mathrm{mmHg}$ ). Cigarette smoke exposure led to a remarkable increase in the bronchoconstricting response to ACh (PIP 18-32 $\mathrm{mmHg}$ ), which served as an index of the development of hyperreactivity. Both oral and intramuscular administration of moguisteine was highly effective in reducing hyperresponsiveness to $\mathrm{ACh}$, with the following ED50 (95\% CL) values: 9.6 (7.7-11.6) $\mathrm{mg} \cdot \mathrm{kg}^{-1}$ p.o. and $0.78(0.57-1.0) \mathrm{mg} \cdot \mathrm{kg}^{-1}$ i.m. (table 1). Dexamethasone elicited a dose-related reduction in hyperresponsiveness with an ED50 (95\% CL) value of $0.81(0.58-1.0)$ $\mathrm{mg} \cdot \mathrm{kg}^{-1}$ i.m. (table 1 ).

Airway leucocyte recruitment. Cytological evaluation of BAL from guinea-pigs exposed to cigarette smoke revealed a significant increase in the number of total cells, and particularly in eosinophils and epithelial cells, in comparison with the unexposed animals (table 2). In our experimental conditions, neutrophils, macrophages and lymphocytes were not modified, and for this reason they are not reported in table 2. Administered, respectively, $90 \mathrm{~min}$ and $7 \mathrm{~h}$ prior to smoke exposure, both moguisteine $\left(30 \mathrm{mg} \cdot \mathrm{kg}^{-1}\right.$ p.o. $)$ and dexamethasone $\left(2.5 \mathrm{mg} \cdot \mathrm{kg}^{-1}\right.$
Table 1. - Effect of moguisteine and dexamethasone on bronchial hyperresponsiveness to acetylcholine (ACh) induced by cigarette smoke inhaled for $15 \mathrm{~s} \cdot \mathrm{min}^{-1}$ for 10 min in anaesthetized male guinea-pigs

\begin{tabular}{lcrc}
\hline \multicolumn{1}{c}{ Treatment } & $\begin{array}{c}\text { Dose } \\
\mathrm{mg} \cdot \mathrm{kg}^{-1}\end{array}$ & $\begin{array}{r}\Delta \mathrm{PIP} \\
\mathrm{mmHg}\end{array}$ & $\begin{array}{c}\text { ED50 (95\% CL) } \\
\mathrm{mg} \cdot \mathrm{kg}^{-1}\end{array}$ \\
\hline Vehicle & - & $23.2 \pm 1.7$ & \\
Moguisteine p.o. & 7.5 & $13.7 \pm 0.4$ & \\
& 15 & $7.6 \pm 0.2$ & $9.6(7.7-11.6)$ \\
Vehicle & 30 & $2.7 \pm 0.2$ & \\
Moguisteine $i . m$. & - & $21.0 \pm 1.4$ & \\
& 0.3 & $14.3 \pm 0.4$ & \\
& 0.6 & $8.8 \pm 0.1$ & $0.78(0.57-1.0)$ \\
Vehicle & 1.25 & $5.4 \pm 0.5$ & \\
Dexamethasone $i . m$. & 0.3 & $18.1 \pm 0.7$ & \\
& 0.6 & $10.0 \pm 0.4$ & $0.81(0.58-1.0)$ \\
& 1.25 & $4.9 \pm 0.2$ & \\
& 2.5 & 0 & \\
\hline
\end{tabular}

Moguisteine was administered either p.o. 90 min before or i.m. $2 \mathrm{~h}$ before cigarette smoke exposure. Dexamethasone was administered i.m. $7 \mathrm{~h}$ before smoke exposure. Data are expressed as increase in pulmonary inflation pressure (PIP) to ACh after cigarette smoking and represent the mean \pm SEM of six animals per group. ED50: median effective dose; 95\% CL: 95\% confidence limit.

Table 2. - Effect of moguisteine and dexamethasone on BAL cell accumulation as induced by cigarette smoke inhaled for $15 \mathrm{~s} \cdot \mathrm{min}^{-1}$ for $10 \mathrm{~min}$ in anaesthetized male guinea-pigs

\begin{tabular}{lccl}
\hline & $\begin{array}{c}\text { Total cells } \\
\times 10^{6}\end{array}$ & $\begin{array}{c}\text { Eosinophils } \\
\times 10^{6}\end{array}$ & $\begin{array}{c}\text { Epithelial cells } \\
\times 10^{6}\end{array}$ \\
\hline Unexposed & $4.1 \pm 0.2$ & $0.9 \pm 0.2$ & $0.5 \pm 0.05$ \\
Vehicle+smoke & $9.4 \pm 0.5^{*}$ & $3.9 \pm 0.7^{*}$ & $1.3 \pm 0.1^{*}$ \\
Moguisteine+smoke & $4.4 \pm 0.1^{* *}$ & $0,7 \pm 0.1^{* *}$ & $0.5 \pm 0.07^{* *}$ \\
Unexposed & $3.9 \pm 0.2$ & $0.4 \pm 0.04$ & $0.5 \pm 0.06$ \\
Vehicle+smoke & $14.3 \pm 0.4^{*}$ & $5.1 \pm 0.1^{*}$ & $2.6 \pm 0.4^{*}$ \\
Dexamethasone+smoke & $3.8 \pm 0.1^{* *}$ & $0.3 \pm 0.03^{* *}$ & $0.6 \pm 0.07^{* *}$
\end{tabular}

Moguisteine (30 mg.kg-1 p.o.) and dexamethasone $\left(2.5 \mathrm{mg} \cdot \mathrm{kg}^{-1}\right.$ i.m.) were administered, respectively, $90 \mathrm{~min}$ and $7 \mathrm{~h}$ before cigarette smoke exposure. Data are expressed as cell number and represent the mean \pm SEM of six animals per group. *: $p<0.05$ compared with unexposed animals; $* *$ : p $<0.05$ compared with smoke-exposed animals. BAL: bronchoalveolar lavage.

i.m.) abolished eosinophil recruitment and epithelial shedding (table 2) at doses that markedly or totally inhibit hyperresponsiveness to ACh.

Airway microvascular leakage. In addition to hyperresponsiveness to $\mathrm{ACh}$ and airway leucocyte infiltration, cigarette smoke inhalation induced a consistent increase (2-4 fold) in vascular permeability, as shown by the rise ( $v s$ basal values) in the extravascular content of Evans blue dye in the trachea and main bronchi (table 3). Given at doses that were fully effective in preventing hyperresponsiveness to $\mathrm{ACh}$, eosinophil recruitment and epithelial shedding, dexamethasone $\left(2.5 \mathrm{mg} \cdot \mathrm{kg}^{-1}\right.$ i.m. $)$ and moguisteine $\left(30 \mathrm{mg} \cdot \mathrm{kg}^{-1}\right.$ p.o.) significantly inhibited 
Table 3. - Effect of moguisteine and dexamethasone on extravasation of Evans blue dye as induced by cigarette smoke inhaled for $15 \mathrm{~s} \cdot \mathrm{min}^{-1}$ for $10 \mathrm{~min}$ in anaesthetized male guinea-pigs

\begin{tabular}{lcccc}
\hline & Trachea & Inhibition & $\begin{array}{c}\text { Main Inhibition } \\
\text { bronchi }\end{array}$ & \\
& $\mathrm{ng} \cdot \mathrm{mg}^{-1}$ & $\%$ & $\mathrm{ng} \cdot \mathrm{mg}^{-1}$ & $\%$ \\
\hline Unexposed & $31 \pm 4$ & - & $33 \pm 4$ & - \\
Vehicle+smoke & $126 \pm 12 *$ & - & $138 \pm 19^{*}$ & - \\
Moguisteine+smoke & $54 \pm 13^{* *}$ & 76 & $60 \pm 4 * *$ & 76 \\
Unexposed & $36 \pm 5$ & - & $38 \pm 4$ & - \\
Vehicle+smoke & $101 \pm 13^{*}$ & - & $91 \pm 6^{* *}$ & - \\
Dexamethasone+smoke & $46 \pm 5^{* *}$ & 84 & $49 \pm 9 * *$ & 80
\end{tabular}

Moguisteine was administered at $30 \mathrm{mg} \cdot \mathrm{kg}^{-1}$ p.o. $90 \mathrm{~min}$ before cigarette smoke exposure, dexamethasone at $2.5 \mathrm{mg} \cdot \mathrm{kg}^{-1}$ i.m. $7 \mathrm{~h}$ before smoke exposure. Data are expressed as ng Evans blue dye per mg of tissue and represent the mean \pm SEM of the results of six animals per group. $*: p<0.05$ compared with unexposed animals. ${ }^{* *}: \mathrm{p}<0.05$ compared with animals treated with vehicle + smoke.

smoke-induced microvascular leakage (table 3). The former compound produced a reduction of $84 \%$ (trachea) and of $80 \%$ (main bronchi), whilst the latter reduced the response by $76 \%$ in both airway tracts.

\section{Airway microvascular leakage induced by capsaicin}

The intratracheal infusion of capsaicin induced a marked increase (about 250-300\%) in microvascular leakage in the trachea and in the right main bronchus and a lower but significant increase (50-100\%) in the left main bronchus [13]. Given at an oral dose of $60 \mathrm{mg} \cdot \mathrm{kg}^{-1}$, moguisteine did not prevent capsaicin-induced Evans blue dye extravasation, irrespective of the pretreatment time. In contrast, at $7.5 \mathrm{mg} \cdot \mathrm{kg}^{-1}$ p.o., dexamethasone inhibited microvascular leakage both in the trachea $(67 \%)$ and in the left $(55 \%)$ and right main bronchus $(71 \%)$.

\section{Bronchial hyperreactivity to histamine induced by PAF}

The remarkable bronchial hyperreactivity to histamine that PAF infusion induced, was apparent in our study as the increase in PIP (17-30 $\mathrm{mmHg}$ ) vs basal values (2-6 $\mathrm{mmHg}$ ). Moguisteine significantly reduced the development of hyperreactivity, with an ED50 (95\% CL) of 11.8 (7.0-16.2) $\mathrm{mg} \cdot \mathrm{kg}^{-1}$ i.d. (table 4). Likewise, the administration of dexamethasone reduced, in a dose-dependent manner, increased airway reactivity to histamine, with an ED50 (95\% CL) of $3.5(3.0-4.1) \mathrm{mg} \cdot \mathrm{kg}^{-1}$ p.o. (table 4).

Bronchoconstriction induced by acetylcholine, histamine and $P A F$

Moguisteine $\left(5 \mathrm{mg} \cdot \mathrm{kg}^{-1}\right.$ i.v.) did not affect bronchoconstriction, measured as PIP, whether induced by ACh $(18.2 \pm 2.2 \mathrm{mmHg}$ vs the basal value: $16.4 \pm 1.8 \mathrm{mmHg}$ ),
Table 4. - Effect of moguisteine and dexamethasone on bronchial hyperreactivity to histamine as induced by PAF infusion (600 $\mathrm{ng} \cdot \mathrm{kg}^{-1}$ over $1 \mathrm{~h}$ ) in anaesthetized male guinea-pigs

\begin{tabular}{lcrc}
\hline & $\begin{array}{c}\text { Dose } \\
\mathrm{mg} \cdot \mathrm{kg}^{-1}\end{array}$ & $\begin{array}{c}\Delta \text { PIP } \\
\mathrm{mmHg}\end{array}$ & $\begin{array}{c}\mathrm{ED} 50(95 \% \mathrm{CL}) \\
\mathrm{mg} \cdot \mathrm{kg}^{-1}\end{array}$ \\
\hline Vehicle & - & $21.6 \pm 2.8$ & \\
Moguisteine $i . d$. & 7.5 & $15.9 \pm 2.1$ & \\
& 15 & $6.6 \pm 2.6$ & $11.8(7.0-16.2)$ \\
Vehicle & 30 & $3.4 \pm 2.0$ & \\
Dexamethasone p.o. & - & $18.5 \pm 2.1$ & \\
& 1.75 & $16.1 \pm 1.3$ & $3.5(3.0-4.1)$ \\
& 3.5 & $9.3 \pm 1.5$ & \\
\hline
\end{tabular}

Moguisteine was given by intraduodenal (i.d.) route $7 \mathrm{~min}$ before PAF infusion, and dexamethasone p.o. $7 \mathrm{~h}$ before PAF infusion. Data are expressed as increase in pulmonary inflation pressure (PIP) to histamine after PAF infusion and represent the mean \pm SEM of 7-8 animals per group. PAF: platelet activating factor. For further definitions see legend to table 1 .

histamine $(13.4 \pm 2.0 \mathrm{mmHg} v s$ the basal value: $14.0 \pm 1.5$ $\mathrm{mmHg})$ or by PAF $(21.8 \pm 3.1 \mathrm{mmHg} v s$ the control group value: $20.3 \pm 2.7 \mathrm{mmHg}$ ).

Late phase airway leucocyte accumulation in sensitized guinea-pigs

Pretreated with mepyramine to avoid acute $\mathrm{H}_{1}$-dependent anaphylactic shock, and challenged with aerosolized $\mathrm{OA}, \mathrm{OA}$-sensitized guinea-pigs developed a late-phase reaction that is characterized by an increase both in neutrophils (17 $\mathrm{h}$ after OA exposure) and in eosinophils (peak: $72 \mathrm{~h}$ after OA) in BAL (table 5). In agreement with published results [12], other cell types, such as macrophages and lymphocytes, did not significantly change in numbers, and are, therefore, not depicted in table 5. With regard to the total cell number, at baseline the value was $6.1 \times 10^{6}$, at $17 \mathrm{~h}$ it was $13.2 \times 10^{6}$ and at 72 h $19.4 \times 10^{6}$. Neutrophils increased from $0.06 \times 10^{6}$ at baseline to $1.9 \times 10^{6}$ at $17 \mathrm{~h}$, and had decreased at 72 $\mathrm{h}$ to $0.5 \times 10^{6}$, a value that was still significantly higher than baseline. Eosinophils rose from $0.7 \times 10^{6}$ at baseline to $3 \times 10^{6}$ at $17 \mathrm{~h}$ and to $7.2 \times 10^{6}$ at $72 \mathrm{~h}$.

At the dose of $75 \mathrm{mg} \cdot \mathrm{kg}^{-1}$ p.o., moguisteine significantly reduced the accumulation of total cells, neutrophils, and eosinophils by 64,84 and $72 \%$, respectively at 17 $\mathrm{h}$; and by 64,90 and $62 \%$ at $72 \mathrm{~h}$. When given at the dose of $150 \mathrm{mg} \cdot \mathrm{kg}^{-1}$ p.o., moguisteine further reduced $(>90 \%)$ the increase in total cell and eosinophil recruitment at both observation times, and neutrophil infiltration at $17 \mathrm{~h}$ (table 5).

In a separate experiment, the effect of dexamethasone at $4,7.5$ and $15 \mathrm{mg} \cdot \mathrm{kg}^{-1}$ p.o. was assessed on the accumulation of cells recovered with BAL. As observed in the moguisteine experiment, the vehicle group showed a similar degree of increase in total cells and leucocytes both at 17 and $72 \mathrm{~h}$ after challenge (table 5). Dexamethasone dose-dependently reduced the recruitment both of neutrophils and eosinophils, as well as the number of 
Table 5. - Effect of moguisteine and dexamethasone on changes in total cells and leucocyte numbers in BAL fluid recovered $17 \mathrm{~h}$ and $72 \mathrm{~h}$ after challenge with aerosolized $2 \%$ OA of sensitized male guinea-pigs

\begin{tabular}{|c|c|c|c|c|c|c|}
\hline & $\begin{array}{c}\text { Total cells } \\
\times 10^{6}\end{array}$ & $\begin{array}{c}\text { Inhibition } \\
\%\end{array}$ & $\begin{array}{l}\text { Neutrophils } \\
\times 10^{6}\end{array}$ & $\begin{array}{c}\text { Inhibition } \\
\%\end{array}$ & $\begin{array}{l}\text { Eosinophils } \\
\times 10^{6}\end{array}$ & $\begin{array}{c}\text { Inhibition } \\
\%\end{array}$ \\
\hline \multicolumn{7}{|c|}{ BAL fluid recovered $\mathbf{1 7} \mathrm{h}$ after challenge } \\
\hline Baseline & $6.1 \pm 0.3$ & & $0.06 \pm 0.01$ & & $0.7 \pm 0.1$ & \\
\hline Vehicle & $13.2 \pm 1.6^{*}$ & & $1.9 \pm 0.3^{*}$ & & $3.0 \pm 0.6^{*}$ & \\
\hline \multicolumn{7}{|l|}{ Moguisteine } \\
\hline $75 \mathrm{mg} \cdot \mathrm{kg}^{-1}$ p.o. & $8.7 \pm 1.0 * *$ & 64 & $0.3 \pm 0.05 * *$ & 84 & $1.4 \pm 0.3 * *$ & 72 \\
\hline $150 \mathrm{mg} \cdot \mathrm{kg}^{-1}$ p.o. & $6.6 \pm 0.5 * *$ & 93 & $0.2 \pm 0.05 * *$ & 93 & $0.9 \pm 0.1 * *$ & 91 \\
\hline Baseline & $7.4 \pm 0.4$ & & $0.07 \pm 0.01$ & & $0.7 \pm 0.1$ & \\
\hline Vehicle & $16.8 \pm 1.2 *$ & & $6.1 \pm 1.4^{*}$ & & $2.5 \pm 0.6^{*}$ & \\
\hline \multicolumn{7}{|l|}{ Dexamethasone } \\
\hline $4 \mathrm{mg} \cdot \mathrm{kg}^{-1}$ p.o. & $12.1 \pm 1.5^{* *}$ & 50 & $2.6 \pm 1.1 * *$ & 58 & $1.8 \pm 0.3$ & 39 \\
\hline $7.5 \mathrm{mg} \cdot \mathrm{kg}^{-1}$ p.o. & $8.3 \pm 0.5^{* *}$ & 90 & $0.4 \pm 0.1 * *$ & 94 & $1.6 \pm 0.2$ & 50 \\
\hline $15 \mathrm{mg} \cdot \mathrm{kg}^{-1}$ p.o. & $6.3 \pm 0.5^{* *}$ & 100 & $0.4 \pm 0.3 * *$ & 94 & $0.9 \pm 0.2 * *$ & 89 \\
\hline \multicolumn{7}{|c|}{ BAL fluid recovered $72 \mathrm{~h}$ after challenge } \\
\hline Baseline & $6.1 \pm 0.3$ & & $0.06 \pm 0.01$ & & $0.7 \pm 0.1$ & \\
\hline Vehicle & $19.4 \pm 1.1 *$ & & $0.5 \pm 0.2 *$ & & $7.2 \pm 0.6^{*}$ & \\
\hline \multicolumn{7}{|l|}{ Moguisteine } \\
\hline $75 \mathrm{mg} \cdot \mathrm{kg}^{-1}$ p.o. & $10.8 \pm 1.7 * *$ & 64 & $0.1 \pm 0.04 * *$ & 90 & $3.2 \pm 0.1 * *$ & 62 \\
\hline $150 \mathrm{mg} \cdot \mathrm{kg}^{-1}$ p.o. & $7.5 \pm 0.7 * *$ & 90 & $0.2 \pm 0.05 * *$ & 70 & $1.3 \pm 0.1 * *$ & 90 \\
\hline Baseline & $7.4 \pm 0.4$ & & $0.07 \pm 0.01$ & & $0.7 \pm 0.1$ & \\
\hline Vehicle & $15.1 \pm 1.1 *$ & & $0.4 \pm 0.2 *$ & & $6.1 \pm 0.6^{*}$ & \\
\hline \multicolumn{7}{|l|}{ Dexamethasone } \\
\hline $4 \mathrm{mg} \cdot \mathrm{kg}^{-1}$ p.o. & $9.0 \pm 0.3 * *$ & 79 & $0.1 \pm 0.07$ & 91 & $2.6 \pm 0.5 * *$ & 65 \\
\hline $7.5 \mathrm{mg} \cdot \mathrm{kg}^{-1}$ p.o. & $7.0 \pm 0.4 * *$ & 100 & $0.1 \pm 0.08$ & 91 & $1.3 \pm 0.3 * *$ & 89 \\
\hline $15 \mathrm{mg} \cdot \mathrm{kg}^{-1}$ p.o. & $6.2 \pm 0.4 * *$ & 100 & $0.1 \pm 0.08$ & 91 & $0.8 \pm 0.1 * *$ & 98 \\
\hline
\end{tabular}

Moguisteine was administered p.o. $90 \mathrm{~min}$ before OA challenge and dexamethasone p.o. $7 \mathrm{~h}$ before OA challenge. Data are expressed as cell number and represent the mean \pm SEM of six animals per group. Baseline: sensitized and saline challenged guineapigs; vehicle: sensitized, OA-challenged and vehicle-pretreated animals. *: $\mathrm{p}<0.05$ compared with baseline values; **: $\mathrm{p}<0.05$ compared with vehicle. BAL: bronchoalveolar lavage; OA ovalbumin.

Table 6. - Effect of moguisteine, dexamethasone, FPL 55712, BW 755C and phenidone on leukotriene-mediated allergic bronchospasm in sensitized and anaesthetized male guinea-pigs

\begin{tabular}{lccc}
\hline & $\begin{array}{c}\text { Dose } \\
\mathrm{mg} \cdot \mathrm{kg}^{-1}\end{array}$ & $\begin{array}{c}\Delta \mathrm{PIP} \\
\mathrm{mmHg}\end{array}$ & $\begin{array}{c}\text { ED50 (95\% CL) } \\
\mathrm{mg} \cdot \mathrm{kg}^{-1}\end{array}$ \\
\hline Vehicle & - & $27.9 \pm 1.3$ & \\
Moguisteine p.o. & 150 & $26.7 \pm 1.2$ & \\
Vehicle & - & $23.6 \pm 1.6$ & \\
Dexamethasone p.o. & 7.5 & $20.5 \pm 1.4$ & \\
& 15 & $12.1 \pm 1.3$ & $12.2(4.7-19.2)$ \\
Vehicle & 30 & $8.6 \pm 0.9$ & \\
FPL 55712 i.v. & - & $33.8 \pm 1.1$ & \\
& 2.5 & $27.0 \pm 1.3$ & \\
& 5 & $14.6 \pm 1.2$ & $4.7(3.6-6.0)$ \\
Vehicle & 10 & $6.5 \pm 0.8$ & \\
BW 755C $i . v$. & - & $27.0 \pm 1.2$ & \\
& 10 & $28.6 \pm 1.4$ & \\
Vehicle & 20 & $14.0 \pm 1.0$ & $20.9(17.9-25.4)$ \\
Phenidone $i . v$. & 30 & $6.5 \pm 0.5$ & \\
& - & $26.8 \pm 1.2$ & \\
& 5 & $25.8 \pm 1.1$ & \\
& 10 & $16.7 \pm 1.6$ & $13.1(10.3-18.7)$ \\
\hline
\end{tabular}

Moguisteine was given p.o. $90 \mathrm{~min}$ before, dexamethasone p.o. $7 \mathrm{~h}$ before, FPL 5572 i.v. $30 \mathrm{~s}$ before, BW $755 \mathrm{C}$ i.v. $5 \mathrm{~min}$ before, and phenidone i.v. 1 min before challenge with aerosolized $1 \%$ OA. Data are expressed as increase in pulmonary inflation pressure (PIP) compared to baseline and represent the mean \pm SEM of 6-10 animals per group. For definitions see legends to tables 1 and 5 . total cells in BAL, at both time-points investigated. At $15 \mathrm{mg} \cdot \mathrm{kg}^{-1}$ dexamethasone almost completely abolished the increase in total cells and eosinophils (table 5).

Leukotriene-mediated allergic bronchospasm in sensitized guinea-pigs

After pretreatment with mepyramine, indomethacin and propranolol and upon OA aerosol challenge, sensitized and anaesthetized animals developed a leukotriene-dependent bronchospasm that was both slow in onset, with a peak at about $15 \mathrm{~min}$ after OA exposure, and prolonged, lasting more than 30 min. Dexamethasone, FPL 55712, BW 755C and phenidone dose-dependently reduced leukotriene-mediated response with respective ED50s (95\% CL) of 12.2 (4.7-19.2), 4.7 (3.6-6.0), 20.9 (17.9-25.4) and $13.1(10.3-18.7) \mathrm{mg} \cdot \mathrm{kg}^{-1}$. Even at $150 \mathrm{mg} \cdot \mathrm{kg}^{-1}$ p.o., moguisteine did not inhibit leukotriene-dependent bronchospasm (table 6).

\section{Discussion}

Moguisteine, a novel, peripheral, nonnarcotic antitussive agent, clearly inhibits certain features of airway inflammation, as assessed in a variety of animal models; the drug is also devoid of bronchodilatory properties. 
Active exposure of guinea-pigs to cigarette smoke induces marked bronchial hyperreactivity (BHR), which is associated with eosinophil infiltration and with sloughing of epithelial cells, along with microvascular leakage in the airway tissues [16-18]. In our study, moguisteine dose-dependently inhibited BHR both after oral and i.m. administration. Given intramuscularly, the inhibitory potency of moguisteine was comparable to that of dexamethasone. At doses required to abolish BHR, moguisteine and dexamethasone totally prevented eosinophil infiltration and epithelial shedding, and significantly reduced microvascular leakage. The causal relationship between leucocyte recruitment and BHR is a matter of debate, as enhanced airway reactivity and inflammatory cell infiltration are not necessarily linked [19]. In previous timecourse studies, we observed that the two events developed simultaneously and ceased within $4 \mathrm{~h}$ [10]: it is therefore possible that they occur independently and that a causal relationship does not exist. On the other hand, a direct relationship between plasma exudation and enhanced airway reactivity has been postulated [16].

Due to the relevance of BHR in airway inflammatory processes, we focused our attention on another model of BHR, namely that induced by PAF infusion in guineapigs. PAF is an endogenous mediator with a wide range of biological actions which, both in animals and in humans, produces several features of airway inflammation, such as increase in airway microvascular permeability, inflammatory cell recruitment and BHR [20]. Moguisteine proved highly effective, as did dexamethasone, in reducing the development of BHR induced by PAF infusion, at the same dosages that are active in preventing pathological changes in the airways induced by cigarette smoke exposure. The highest dose, $30 \mathrm{mg} \cdot \mathrm{kg}^{-1}$ p.o., completely prevented BHR, as observed for cigarette smoke exposure (table 4).

Besides the inhibition of cigarette smoke-induced eosinophil recruitment, we assessed moguisteine's effect on the inflammatory reaction which is associated with a characteristic clinical response. In atopic subjects, the inhalation of allergens elicits an immediate airway asthmatic response (early asthmatic response (EAR)), followed by a late asthmatic response (LAR) [21], which has been shown to be associated with inflammatory reactions characterized by neutrophil and eosinophil airway infiltration [22]. Using several of the antigen and sensitization procedures leading to the development of LAR, research now makes use of a variety of animal models [23]. Our studies were undertaken on OA-sensitized guinea-pigs that were challenged with aerosolized OA [12], with the aim of simulating the allergen exposure that is typical in humans. We confirm that LAR is characterized by two delayed responses: a marked influx of neutrophils and of eosinophils in BAL $17 \mathrm{~h}$ after OAchallenge; a neutrophil decrease towards baseline values and a further increase in eosinophil $72 \mathrm{~h}$ after OAchallenge. In this model, at doses 2-5 times higher than those required for the antitussive effect, moguisteine, like dexamethasone, significantly reduced the recruitment of neutrophils and eosinophils assessed in BAL at 17 and $72 \mathrm{~h}$ after OA- challenge. In our experiments, the effect on inflammatory cell recruitment was assessed only in BAL, and not through morphometric studies of the airways. However, BAL is a widely-accepted and commonly used method for such studies in animals. Differences have been observed between leucocyte composition in BAL and in airway tissue $[24,25]$. The kinetics of cell migration from the tissues to the airway lumen could account for the observed discrepancy [25]. This discrepancy implies that evaluation of airway leucocyte recruitment should calibrate timing after challenge to the method used, be it BAL or histology. In any case, both techniques are useful in measuring airway inflammation.

The anti-inflammatory effect displayed by moguisteine was obtained at doses that fall within the range of those effective in experimental cough [5], except for its activity on cell recruitment in sensitized animals which required higher doses. Moguisteine's lower potency in this case is possibly explained by the greater severity of the given experimental model, such as the immunological rather than chemical nature of the stimulus used, and the longer time-lag to leucocyte accumulation that that stimulus implies. Moguisteine selectively exerts its antiinflammatory effect at the airway level, since it is devoid of activity in carrageenan-induced paw oedema in rats at up to $300 \mathrm{mg} \cdot \mathrm{kg}^{-1}$ p.o. (data not shown).

The mechanism of action of moguisteine is far from being understood. For the time being, we can exclude the hypothesis of antagonism against PAF receptors, since the drug did not antagonize the acute bronchoconstriction elicited by this agonist. In this connection, we also addressed the question of whether moguisteine interacts with substance P. Recent studies suggested that substance $\mathrm{P}$ released from sensory nerves in the airways may be an endogenous substance causing cough [26]. In guinea-pigs this neuropeptide also causes airway inflammation, which appears as an increase in plasma protein extravasation [27]. Moguisteine does not inhibit capsaicin-induced airway microvascular leakage, which is provoked by the release of substance $\mathrm{P}$ from the peripheral endings of sensory nerves [27]. Moguisteine dosedependently reduces cough induced by capsaicin [5], but this is not a contradictory result as the two responses are mediated by different mechanisms: cough, by the sensory receptors along the airways [28], plasma leakage by a direct effect on postcapillary venular endothelial cells [29]. These findings suggest that the anti-inflammatory effect of moguisteine is not mediated by substance P-antagonistic activity.

It is also unlikely that moguisteine interacts with leukotrienes, since the drug was inactive against leukotrienemediated allergic bronchospasm, in contrast with FPL 55712 (an antagonist of the leukotriene receptors) BW $755 \mathrm{C}$ and phenidone, all of which inhibit leukotriene biosynthesis. Through the use of receptor antagonists or biosynthesis inhibitors, leukotrienes have been shown to be involved not only in early bronchoconstriction, but also in LAR [30]. As moguisteine proved to be active in LAR, it is plausible to suppose that other mechanisms play an important role in the development of LAR. Airway inflammation is a complex and less than fully understood 
process, and our lack of knowledge particularly regarding: the sequence of events after initiation of the allergic response; the way in which different mediators interact with each other and with different cells; the positive and negative feedback systems [30]. We cannot, therefore, exclude that moguisteine acts through mechanisms other than those (the commonest and the easiest to assess) considered here. It is possible, for example, that moguisteine acts on airway inflammatory cell chemotaxis and/or degranulation.

In conclusion, we show that moguisteine is endowed with interesting inhibitory effects on the airway inflammatory process in guinea-pigs in vivo; in addition to its antitussive properties, the drug could represent an improved and innovative approach to cough therapy.

\section{References}

1. Irwin RS, Corrao WM, Pratter RM. Chronic persistent cough in the adult: the spectrum and frequency of causes and successful outcome of specific therapy. Am Rev Respir Dis 1981; 123: 413-417.

2. Editorial. Cough and wheeze in asthmatics: are they independent? Lancet 1988; i: 447-448.

3. Choudry NB, Fuller RW, Pride NB. Sensitivity of the human cough reflex: effect of inflammatory mediators, prostaglandin $\mathrm{E}_{2}$, bradykinin, and histamine. Am Rev Respir Dis 1989; 140: 137-141.

4. Gallico L, Borghi A, Dalla Rosa C, et al. Moguisteine, a new drug effective in experimental cough and hyperreactivity. Am Rev Respir Dis 1990; 141 (Suppl.): A654.

5. Gallico L, Borghi A, Dalla Rosa C, Ceserani R, Tognella S. Moguisteine: a novel peripheral nonnarcotic antitussive drug. Br J Pharmacol 1994; 112: 795-800.

6. Adams R, Hosie J, James I, et al. Antitussive activity and tolerability of moguisteine in patients with acute cough: a randomized, double-blind, placebo-controlled study. Adv Therapy 1993; 10: 263-271.

7. Aversa C, Cazzola M, Clini V, et al. A double-blind, placebo-controlled, parallel group clinical trial on efficacy and safety of moguisteine in patients with cough associated to chronic respiratory diseases. Drugs Exp Clin Res 1993; XIX: 273-279.

8. Del Donno M, Aversa C, Corsico R, et al. Efficacy and safety of moguisteine in comparison with dextromethorphan in patients with persistent cough. Drug Invest 1994; 7: 93-100.

9. Fasciolo G, Nicolini A, Vacca N, Viglierchio P. Efficacy and safety of moguisteine in comparison with levodropropizine in patients with cough associated with COPD, lung cancer or pulmonary fibrosis. Current Ther Res 1994; 55: 251-261.

10. Gallico L, Oggioni N, Dalla Rosa C, Lumachi B, Tofanetti $\mathrm{O}$, Tognella S. Tobacco smoke-induced hyperreactivity in guinea-pigs: effect of dexamethasone and salbutamol. Am Rev Respir Dis 1990; 141 (Suppl.): A840.

11. Robertson DN, Page CP. Effect of platelet agonists on airway reactivity and intrathoracic platelet accumulation. Br J Pharmacol 1987; 92: 105-111.

12. Hutson PA, Church MK, Clay TP, Miller P, Holgate ST. Early and late bronchoconstriction after allergen challenge of nonanesthetized guinea-pigs. 1. The association of disordered airway physiology to leukocyte infiltration. Am Rev Respir Dis 1988; 137: 548-557.

13. Gallico L, Ferrario A, Piazzoni L, Ceserani R. Capsaicin induces differing microvascular leakage in left and right main bronchus of guinea-pigs. Med Sci Res 1993; 21: 755-766.

14. Kreutner R, Sherwood J, Rizzo C. The effect of leukotriene antagonists, lipoxygenase inhibitors and selected standards on leukotriene-mediated allergic bronchospasm in guinea-pigs. Agents Actions 1989; 28: 173-184.

15. Dunn OJ. Multiple comparisons among means. J Am Stat Assoc 1961; 56: 52-64.

16. Hulbert WC, McLean T, Hogg JC. The effect of acute airway inflammation on bronchial reactivity in guinea-pigs. Am Rev Respir Dis 1985; 132: 7-11.

17. James AL, Dirks P, Ohtaka H, Schellenberg RR, Hogg JC. Airway responsiveness to intravenous and inhaled acetylcholine in the guinea-pig after cigarette smoke exposure. Am Rev Respir Dis 1987; 136: 1158-1162.

18. Hulbert WC, Walker DC, Jackson A, Hogg JC. Airway permeability to horseradish peroxidase in guinea-pigs: the repair phase after injury by cigarette smoke. Am Rev Respir Dis 1981; 123: 320-326.

19. Chapman ID, Foster A, Morley J. The relationship between inflammation and hyperreactivity of the airways in asthma. Clin Exp Allergy 1993; 23: 168-171.

20. Page CP. The role of platelet activating factor in allergic disease. Br J Clin Pharmacol 1990; 30: 99S-106S.

21. Robertson DG, Kerigan AT, Hargreave FE, Chalmers R, Dolovich J. Late asthmatic responses induced by ragweed pollen allergen. J Allergy Clin Immunol 1974; 54: 244-254.

22. De Monchy JGR, Kauffman HF, Venge P, et al. Bronchoalveolar eosinophilia during allergen induced late asthmatic reactions. Am Rev Respir Dis 1985; 131: 373-376.

23. Smith H. Animal models of asthma. Pulm Pharmacol 1989; 2: 59-74

24. Iljima H, Ishi M, Yamauchi K, et al. Bronchoalveolar lavage and histologic characterization of late asthmatic response in guinea-pigs. Am Rev Respir Dis 1987; 136: 922-929.

25. Boichot E, Lagente V, Carre C, Waltmann P, MenciaHuerta JM, Braquet P. Bronchial hyperresponsiveness and cellular infiltration in the lung of guinea-pigs sensitized and challenged by aerosol. Clin Exp Allergy 1991; 21: $67-76$

26. Ujiie Y, Sekizawa K, Aikawa T, Sasaki H. Evidence for substance $\mathrm{P}$ as an endogenous substance causing cough in guinea-pigs. Am Rev Respir Dis 1993; 148: $1628-1632$.

27. Saria A, Lundberg JM, Skofitsch G, Lembeck F. Vascular protein leakage in various tissues induced by substance $\mathrm{P}$, capsaicin, bradykinin, serotonin, histamine and antigen challenge. Naunyn Sch Arch Pharmacol 1983; 324: 212-218.

28. Mohammed SP, Higenbottam TW, Adcock JJ. Effects of aerosol-applied capsaicin, histamine and prostaglandin $\mathrm{E}_{2}$ on airway sensory receptors of anaesthetized cats. $J$ Physiol 1993; 469: 51-66.

29. Erjefält I, Persson CGA. Inflammatory passage of plasma macromolecules into the airway wall and lumen. Pulm Pharmacol 1989; 2: 93-102.

30. Alabaster VA, Moore BA. Drug intervention in asthma: present and future. Thorax 1993; 48: 176-182. 